Portland State University

PDXScholar

Political Science Faculty Publications and

Presentations

Political Science

$11-22-2020$

\title{
Eco-Critique and Thought As a Force of Nature
}

Stephanie Erev

Portland State University, erev@pdx.edu

Follow this and additional works at: https://pdxscholar.library.pdx.edu/polisci_fac

Part of the Political Theory Commons

Let us know how access to this document benefits you.

\section{Citation Details}

Erev, S. (2020). Eco-Critique and Thought as a Force of Nature. New Political Science, 1-7.

This Post-Print is brought to you for free and open access. It has been accepted for inclusion in Political Science Faculty Publications and Presentations by an authorized administrator of PDXScholar. Please contact us if we can make this document more accessible: pdxscholar@pdx.edu. 


\section{Eco-Critique and Thought as a Force of Nature}

Stephanie Erev

It occurred to me not long ago that each time I read something new I pay special attention, without really meaning to, to how the work projects forward into a future or futures. This has been going on, I now think, for some years. Perhaps this quasiconscious reading practice has played a part in the recalibration of my own orientations to the future, which, with every new climatic event, seem to grow dizzier and more disorganized, feeling some of the time like players in a game of musical chairs. Whether it be in relation to "All Around the Mulberry Bush" or something else, the visceral feeling that tunes most familiar to you - tunes that, indeed, have helped to compose your being - could cut out at any time can, to be sure, take a toll. After a while, even despairing visions of the future may exert an appeal as the degree of uncertainty you must swallow to remain open to what may come seems only ever to move in one direction. But I have come to think that, politically speaking, resisting the urge to plunk down on the nearest chair can make a difference. For, at least some of the time, we pay for resolution in attachment to this world.'

Reading Timothy Luke's Anthropocene Alerts prompted me to reconsider this thesis. Beyond highlighting Luke's perceptive and forward-looking thinking, the volume documents the longstanding tendency in his work to rethink critical theory with attention to ecology. By developing critical theory's critique of reason, Luke has offered a much-needed model of what a theory would have to do in order to measure the extent of the damage - planetary, political, personal, and so forth-being done. That model is what Luke calls "ecocritique," or "the relentless contestation of the politics of nature, economy, and culture as the core of a critical theory of the contemporary.". Another key takeaway from the volume concerns the indispensability

\footnotetext{
'Derrick Bell's "racism is permanent" thesis may suggest the most pertinent and interesting contrast to this view. See Bell, Faces at the Bottom of the Well: The Permanence of Racism (New York: Basic Books, 1992).

${ }^{2}$ Timothy W. Luke, Anthropocene Alerts: Critical Theory of the Contemporary as Ecocritique (Candor, NY: Telos), I.
} 
of attention to political economy in eco-politics. I continue to learn from Luke on this score. But I also wonder if greater explicit attention to ecological proces ses and forces - to nature's own powers and propensities - might have altered the analytic tone one hears across the essays in this volume. For my reading suggests that an early sense of possibility in the text dims over time. Its concluding engagement with the work of Theodor Adorno may suggest that, given the present reach of climate and biodiversity crises, few possibilities remain to inflect our existing ecocidal consumption and production practices in more just and eco-viable directions.

If Luke is perhaps uncertain whether by now anything can actually be done, he may believe that critical theory in the form of ecocritique offers the best, or even only, hope of clawing out a viable and worthy path ahead. True, select chapters contain affirmative engagements with figures not typically cast within traditions of critical theory - Edward Abbey, for instance, and Ted Kaczinsky, whose "manifesto," Luke says, "makes so many valid criticisms against industrial society that it cannot be ignored."3 But it sometimes seems as if the study's numerous other interlocutors are regarded as downright clueless, dangerous, or both. Three categories of interlocutor, not necessarily mutually-exclusive, stood out to me in particular the categories are mine, not Luke's). First are the aspiring techno-masters - among them sustainability scientists, earth system scientists, and "Anthropocenarians" — who seek to understand earth processes in order to control them and whose politics embody a similar topdown technocratic ethos. Then there are the mystifiers: arcologists, for example (although "dressed in the garb of theological celebration," Paolo Soleri's arcology is actually "a tremendous megamachine..."), at least some eco-activis ts ("one soon realizes that most eco-activism is a scam"), and, perhaps, deep ecologists. Finally, one encounters the rosy dupes, the ecopoets, new materialists, and environmental literary critics who lack courage "to face the contradictions of contemporary reality" and whose "pathetic pleas to each other" to "end environmental racism or technocapitalist waste as we know it" fail even to question "what is really being made lyrical in a society rendering itself and its detritus into stone." 4 Not so closely aligned with critical theory myself - I rather suspect my political-theoretical proclivities lump me in among

${ }^{3}$ Luke, Anthropocene Alerts, 58.

${ }_{4}^{4}$ Luke, Anthropocene Alerts, 294-295. 
the dupes! - in the remainder of this essay, I will draw from the work of a few thinkers in other traditions in order to explore some possibilities of ecocritique that emerge when thought is understood not only in terms of "reason," but also as processes that, while distinctive, are not exceptional among the many diverse processes of nature. ${ }^{5}$ To play up how critique, when understood in this way, is always advanced in relation to specific ecological processes (or "forces"), I will refer to my spin on Luke's concept as eco-critique from now on.

While what I mean by eco-critique will be fleshed out more fully as the essay progresses, let me say a few additional words about it here. Criticism, as I understand it and as Michel Foucault writes, "does not consist in saying that things are not good as they are"; rather, it "consists in seeing what kinds of self-evidences [évidences], liberties, acquired and non-reflective modes of thought, the practices we accept rest on." 6 The conceit of criticism understood in this way is that to think in a different way is also, at least in some sense, to live in a different world - that, in the words of Alfred North Whitehead, "as we think, we live."7 Explaining why for him criticism is so crucial in politics, and why reform and critique are not opposed or even fully separate, Foucault says: "thought often hides itself, but it always animates everyday behavior. There is always a little bit of thought even in the silliest institutions, always some thought even in mute habits." If you have heard about the scientists who-concerned that intensifying hurricanes are distorting meteorological classifications - suggest the need for a new class of storm, that of the Category 6 hurricane, you may be wondering to yourself about my suggestion: greater explicit attention to nature's own powers can inspire a stronger sense of future possibility? But we do not only imagine or otherwise

\footnotetext{
${ }^{5}$ In referring to thought as a force of nature in the title of this essay, I am not suggesting the existence of any kind of universal spirit which need only be put back in control in order for harmony to be restored. Like Luke, I admire certain aspects of deep ecology even as I am at odds with the major ontologies and modes of politics associated with that tradition. For a longer discussion, see Erev, "What Is It Like to Become a Bat? Heterogeneities in an Age of Extinction," Environmental Humanities Io, no. I (20і8): 129-I 49 .

${ }^{6}$ Foucault, "Is It Really Important To Think? An Interview with Michel Foucault translated by Thomas Keenan," Philosophy \& Social Criticism 9, no. I (1982): 30-40, 33. 7 Alfred North Whitehead, Modes of Thought (New York: The Free Press, ig68), 63. ${ }^{8}$ Foucault, "Is It Really Important To Think?," 33.
} 
represent the future; we also feel the passage of thens into nows, of nows verging onto...who-knows-what's coming into being. Taking up Foucault's notion of criticism as "the work of thought on itself" in an expansive way, I'll explore certain material practices of relating-otherwise to the bodies and forces of the earth as practices of eco-critique. ${ }^{9}$ The essay concludes with a few remarks on the politics of eco-critique understood as what Anna Tsing and others call an art "of living on a damaged planet."”o

\section{On the Nature of Critique}

Reading Anthropocene Alerts, one is struck by its author's prescience. Let me show you what I mean:

1980: The Left is presently in crisis since, like the system it opposes, it refuses to acknowledge the ecological constraints limiting further developments of advanced industrial societies."

1983: [S] ome observers...see a post-industrial informationalized society as an environmentally sound economic order. [...] Instead, informational capital's program for cybernetically managing the earth's ecological collapse from space must be recognized as an environmental false promise that neither America's neoconservatives nor its neoliberals can really fulfill. ${ }^{2}$

These claims support the objection Luke raises to "Anthropocenarians" and others that, in fact, plenty of people have been calling out the planetary dangers of extractive capitalism for decades. His critique of the Anthropocene concept, understood "as a valid scientific benchmark," as well as of the motives of those "pushing to ratify" it as such addresses two related dangers. Briefly, he worries - I think rightly-that such a

\footnotetext{
9 Ibid., 34-35.

1o Anna Tsing, Heather Swanson, Elaine Gan, and Nils Bubant (eds), Arts ofLiving on a Damaged Planet (Minneapolis: University of Minnesota Press, 20I7).

"Luke, Anthropocene Alerts, 7 .

${ }^{12}$ Ibid., 26.
} 
species-level focus flattens crucial distinctions, failing to capture, for example, how "many suffer considerably, while only a few profit tremendously" from the destructive processes under way. And he further criticizes the sorts of politics that the Anthropocene idea seems to him likely to authorize and promote: "[t]hey rule, and all others will follow their rules."4 In Luke's case, by contrast, the alarms have been intended not only to warn others of dangers to come, but also to promote political activism that might inflect existing political and economic processes in more ecopopulist directions. By "eco-populism" I take Luke to envision a largely though not exclusively restorative political project, one that aims to restore to regional communities the capacities to define and meet their own needs while also restoring nature "directly into everyd ay life in more subjective aesthetic or ethical forms" restoring (many) people's sense, that is, that nature is and "must be treated as an equal vital presence." least two reasons: first, rather than calling for the abolition of modern technologies, he at one point highlights the potential promise of "a populist "ecotechnics" which would wrest control of existing technologies from corporations and centralized state power in order to afford individuals and communities the means to attain "a downsized but satisfying standard of living"16; and he also seems to regard at least certain historical formations of power-knowledge to be in some respects indelible, and thus envisions the need to re-appropriate such formations towards more just ends.

Luke's study points readers to minor fissures or "contradictions" in the existing order which, after rigorous critical examination, might be exploited in order to turn things around. Consider two examples. Luke writes in 1995 that even as recent instantiations of populism arise "out of advanced industrialism," they are not predestined to do its bidding. Noting that "even the most system-affirming corporate technologies contain self-subversive moments," he argues that the system of "bureaucratically controlled consumption...can be undone" by "destructively reconstituting pieces and parts of its institutions, technologies, and values in a new

\footnotetext{
${ }^{3}$ Ibid., 2 I2.

4 Ibid., 226.

ı̌ Ibid., 85.

${ }^{16}$ Ibid., 135 .
} 
ecological "doing"” ${ }^{77}$ In I983 Luke notes how, "to compensate for the withering away of public goods," those invested in saving capitalism might "simulate" the provision "of free schools, neighborhood councils, backyard gardening, and frugality philosophies." Yet with determined efforts in the medium term, he says, ecological political action might coopt "these alternative institutions and techniques" in order to develop "a more rational, equal, and participatory society through self-reliance and communal interaction." 18

On my reading, however, partway through the essays collected here this sense of possibility fades; one must look harder for an opening through which positively to respond to new "alerts" being issued. In conversation with Adorno - who, it is argued, managed always to retain a "spirit of hope" and, to my ears, perhaps somber tone: "[a]t best," Luke says, "if there is some good to be found, the environmental speculations in Anthropocene discourses are perhaps only the latest mystified 'allegories of the possibility' that allow some to believe we now are defying doom." Ifo critical theory as ecocritique promised at least the possibility of "reorder[ing] everyday life" earlier on ${ }^{21}$ I am not sure that the same degree of faith in its (or any other) approach persists today; although the volume's most recent essay calls for ongoing genesis of ever-more ecocritique, the projected payoff of such efforts is that, with the insights generated, "collapse need not be complete..." ${ }_{22}$

I am not confident that Luke's outlook has changed in the way described. If it has, though, this would seem to mark a departure from another tendency in his thinking, too. I refer to Luke's tendency to affirm a variable degree of opennes s in even the most entrenched systems of thought and control. This tendency finds expression when, reflecting upon the outsized influence of the political-economic processes of informational capitalism (among other capitalisms) criticized throughout the text, Luke says: "control is never total, no concept exhausts the pre-categorical fullness of life,

\footnotetext{
17 Ibid., I33, І34.

${ }^{8}$ Ibid., 43 .

19 Ibid., 303.

${ }^{20}$ Ibid., 3o3, quoting Adorno, "Mammoth."

${ }^{21}$ Luke, Anthropocene Alerts, 43 .

${ }^{22}$ Ibid., 15.
} 
humanity evinces its worthiness against domination, and degradation is not yet absolute destruction." ${ }^{23}$ Also, in earlier chapters, each time a fissure or "contradiction" is called to light, Luke is careful to note that there are no guarantees. With this, I think, he seeks to caution as well as to egg on: something about the conditions of this world make it such that the consequences of eco-populist efforts are not fully determined by those efforts, just as the ultimate effects of capitalist processes are not wholly at the whim of those pulling the strings. What, though, is that something? What explains why being exceeds identity? Why control is never total? And what does it have to do with human dignity?

Like Luke (and Adorno), Friedrich Nietzsche is skeptical of scientific approaches claiming or even aspiring to conquer the unknown. To him such "pale atheisms" express the spirit of ressentiment, a form of resentment arising not in response to a specific injury or harm received, but rather to the most basic con ditions of your existence (whatever you understand those to be). Besides, the idea of total knowledge is an absurdity to Nietzsche, as it implies a perspective beyond perspectivity - and absolute, rather than relational, identities of knower and known. But such identities are actually entangled; coming to know something is also to change it and to be changed by it in turn. "Something unconditioned cannot be known," Nietzsche needles Kantians in an aphorism entitled Against the scientific prejudice; "otherwise it would not be unconditioned!"’ He continues: "[c] oming to know means 'to place oneself in a conditional relation to something'; to feel oneself conditioned by something and oneself to condition it - ." wrench in reductivist materialist philosophies of nature, which, Nietzsche thinks, express "the faith in a world that is supposed to have its equivalent and its measure in human thought and human valuations" - a world "that can be mastered completely and forever with the aid of our square little reason." ${ }^{26}$ Despite the many readings of Nietzsche that proclaim him an "irrationalist," Nietzsche's gripe is not with reason or

\footnotetext{
${ }^{23}$ Ibid., 3 oo.

${ }^{24}$ Fried rich Nietzsche, The Will to Power, Walter Kaufmann (ed.), translated by Walter Kaufmann and R.J. Hollingdale (New York: Vintage Books, I968), \#555.

${ }^{25}$ Ibid.

${ }_{26}^{6}$ Nietzsche, The Gay Science: With a Prelude in Rhymes and an Appendix of Songs, translated by Walter Kaufmann (New York: Random House, I974), 335 (\# 373).
} 
reasoning per se; it is, rather, with the demand that existence itselfbe rational. Such a demand is not only dangerous; it is also depleting:

What? Do we really want to permit existence to be degraded for us like this reduced to a mere exercise for a calculator and an indoor diversion for mathematicians? Above all, one should not wish to divest existence of its rich ambiguity: that is a dictate of good taste, gentlemen, and taste of reverence for everything that lies beyond your horizon. ${ }^{27}$

For Luke's Adorno, the method most appropriate to meditating "about damaged life on a damaged planet" is "Nietzsche's philosophy as melancholic science." ${ }^{8}$ To me, Nietzsche's science is a gay science, and I find its emphasis upon affirmation and the irreducible element of wildness in being-its affirmation that, in Anna Tsing and fellow editors' words, "[l] ife has been mons trous almost from its beginnings" ${ }_{9}$ fruitful starting point from which to explore how eco-critique could figure among the many arts of living on a damaged planet needed today.

Please do not get me wrong. Suggesting the importance of affirmation in ecopolitics is not, to put the point as a critic might, to suggest that all we need to do is smile for everything to turn out okay. As I write this, federal agents kidnap protestors demanding an end to America's ruthless, systemic violence against Black people; a global pandemic decimates untold lives and livelihoods around the world; millions of people suffer needlessly even in wealthy countries following decades of state divestment and a "just-in-time" ethos which left hospitals under-staffed and -supplied despite repeated warnings from public health experts of pandemics to come; rates of domestic violence skyrocket as so many victims find themselves trapped in their homes; missionaries, exploiting the global crisis, invade Indigenous lands and spread disease while miners and other land-grabbers continue their pillaging crusades; the Trump administration quietly (and not so quietly) accelerates its relentless campaign to plunder the earth - and the animal, plant, and human-animal bodies, many of them Brown and Black, obstructing its way - in what appears increasingly like a murdersuicide on a massive scale. Affirming the element of unruliness or wildness in things -

\footnotetext{
${ }^{77}$ Ibid. (emphasis in original).

${ }^{28}$ Luke, Anthropocene Alerts, 3 oo.

${ }^{29}$ Tsing et al, Arts of Lising, M5.
} 
and in us - is not sufficient to bring about more beautiful, anti-racist eco-egalitarian futures. But it can render such efforts better attuned to minor fissures when and where they emerge. Said another way, it can prime such efforts to ride the wave of cracks now rippling across existing institutions and habits of desire thanks to extraordinary and long overdue mass protests, but also to the relentless assault of a microscopic virus and ever more frequent pulses of climate disorder.

Back to eco-critique and arts of living on a damaged planet. To review, I discuss such arts in terms of eco-critique not only because I share Luke's conviction that critique today must issue from expressly ecological perspectives. I also do so (this time moving away, perhaps, from ecocritique in Luke's sense) because I want to explore how eco-forces can be und ers tood to participate in critical practices in ways that render such practices potentially more risky but also up the chances of their achieving something important and worthwhile. To do so, I am taking up Foucault's criticism as "the work of thought on itself" in an expansive way, to include certain material practices, too. ${ }^{30}$

An example can be found in the work of Jamaica Kincaid. Like Luke, Adorno, and Nietzsche, Kincaid also criticizes Euro-Enlightenment modes of thought or "reason." But her work focus es largely on how such modes of thought animated the attempted genocide of native Caribbean peoples and the kidnapping and enslavement of native peoples of Africa. ${ }^{31}$ I say largely because Kincaid's work explores the ways these murderous campaigns were bound up with another imperial project of that period: taxonomy, or the classification of earth's many diverse species according to a universal putatively objective scheme. As one consequence of this "universalizing knowledge project," numerous peoples of the earth soon lost vital categories of experience and expectation as local names for and ways of relating to heterogeneous "earth others"

\footnotetext{
3o Foucault, "Is It Really Important to Think?," 34-35.

${ }^{31}$ Jamaica Kincaid's essay "Ovando" may represent her most sustained and trenchant critique of Euro-Enlightenment orientations to self, other, materiality, and time. See Kincaid, "Ovando," Conjunctions I/4 (1989): 75-83. I refer here to attempted genocide as a way to acknowled ge the impressive campaigns of resistance waged by so many native peoples against the conquistadors. But it is possible that use of the term is inappropriate in this context; Kincaid's grandmother was Carib Indian, a people Kincaid has suggested did not actually survive European "contact."
} 
were displaced by the grand new order of things. ${ }^{32}$

Kincaid explains that it was while working in her first garden that she realized "you could write a history of an empire through plants." 33 Michael Shapiro has noted how, for Kincaid, gardening is also "“an exercise in memory." "34 In gardening Kincaid finds "a way of remembering my own immediate past, a way of getting to a past that is my own." 35 In this way, Shapiro suggests gardening can be understood as "a practice of counter-memory, a recoding and recovery of the world effaced by the botanical part of imperialism's coding practices." ${ }^{36}$ Although not emphasized in Shapiro's thoughtful reading, attention to how natural beings and processes often assume "ethical forms" and "possess an equal vital presence" in Kincaid's work invites consideration, in a speculative way, of whether the other diverse materialities present on the scene play a part in the practice. Kincaid writes, for example, of her activities in the garden one day: "I moved the Scabiosa ochroleuca into the yellow bed - it is yellowish and tall and airy and wants to go everywhere it feels will be susceptible to its presence $(\mathrm{I}$ am reminded of myself, except for the yellowish part)." ${ }^{37}$

For people who, like some of my ancestors, may have internalized white supremacy's justification for their subordination the claim that subjectivity and culture arise from domination of nature), restoring nature to ethics and a sense of its vital presence - which, like Luke, I take to be crucial to any viable ecopolitics todayrequires first affirming the nature within. While not quite a movement, perhaps, an emerging tendency in this direction exists - for example, at the Black Futures Farm in

\footnotetext{
32. The concept of "earth others" is Val Plumwood's. On the Enlightenment's "universalizing knowledge project," see Michael J. Shapiro, "Securing the American Ethnoscape," in Deforming American Political Thought: Challenging the Jeffersonian Legacy (Taylor and Francis, 20I6), ı5.

33 Kathleen M. Balutansky and Jamaica Kincaid, "On Gardening: An Interview with Jamaica Kincaid," Callaloo 25, no. 3 (2002): 790-80o, 793.

${ }_{34}$ Kincaid, My Garden (Book): (New York: Farrar, Strauss and Giroux, I999), 8, quoted in Shapiro, "Securing the American Ethnoscape," I5.

${ }^{35}$ Kincaid, My Garden (Book):, 8.

${ }^{36}$ Shapiro, "Securing the American Ethnoscape," I5.

37 Kincaid, My Garden (Book): , 27.
} 
This article has been accepted for publication in Nex Political Science, published by Taylor \& Francis. It appears online at https://doi.org/I0.1080/07303148.2020.1847534.

Portland, Oregon, whose stated aim is "to restore Black people to the land." 38 One need not ignore the perils of the present, nor even take a rosy outlook on these emerging practices to see that they are already changing selves and worlds.

38 See Crystal Ligori and Jenn Chavez, “A Portland Farm Seeks to Restore Black People to the Land," Oregon Public Broadcasting/OPB.org (July 2I, 2020), available online at: https://www.opb.org/news/article/black-futures-farm-portland-agriculture-black-food-sovreignty/. 